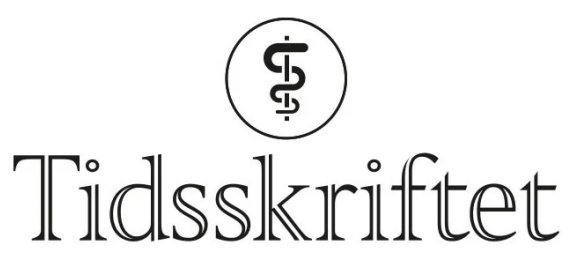

DEN NORSKE LEGEFORENING

\title{
MINNEORD
}

\author{
LEGELIVET
}

DAG ANDREASSEN

\section{SVEIN HINDAL}

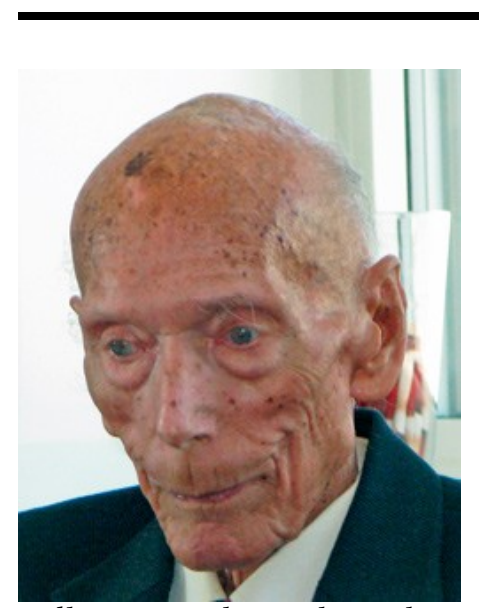

Tidligere overlege Eilert Eilertsen døde 96 år gammel 24. februar 2014. Han ble utdannet $\mathrm{i}$ Oslo i 1946, spesialist i lungesykdommer i 1953 og Master of Public Health, Harvard, i 1958. Hans desidert lengste arbeidsforhold var som overlege ved Lungeavdelingen, Bergen Helseråd, og som sjef for Hordaland fylkes sentrale diagnosestasjon 1954-1985. En meget betydelig og markert kliniker, samfunnsmedisiner og samfunnsbygger er nå borte.

Eilertsen deltok i motstandskampen med offiserskurs i Sverige, tjeneste i Kompani Linge, og han virket som feltlege for Bjørn West i Masfjord-fjellene våren 1945. Han var første brigadelege, major, i Tysklandsbrigaden 1946-47. Han var også sjeflege for Den internasjonale tuberkulosekampanjen i Italia 1949-50.

Ut over stillingen som overlege i Bergen, bl.a. som bestyrer noen år ved Institutt for hygiene og sosialmedisin, Universitetet i Bergen, og i undervisning av studenter og lungeleger m.v. hadde Eilertsen ulike oppdrag. I 16 år var han spesiallege ved Kysthospitalet i Hagevik. Han var en av de fremste legene i kampen mot tuberkulosen, med bred innsats innen forebygging, diagnostikk og behandling. Pasientene skulle ha adekvat terapi og oppfølging. Han la stor vekt på miljøundersøkelser og oppsporing av smittekilder.

Vi arbeidet sammen med ham i Helserådet, der alle opplevde ham som en redelig, dyktig og bestemt leder og kollega. I tillegg til all virksomhet i Bergen og Hordaland var han en engasjert fagperson som ble mye benyttet av sentrale helsemyndigheter. Han publiserte en rekke artikler og holdt ofte foredrag, både i Norge og internasjonalt. I 1964 presenterte han 
et viktig arbeid med 27 års oppfølging av barn og unge med tuberkulose. Eilertsen kunne med stor interesse og glede følge den radikale reduksjonen i sykelighet og dødelighet i Norge av tuberkulose i sin yrkesaktive periode.

Han var også en engasjert politiker, først som representant i Fana og senere i bystyret i Bergen. Han var ordfører i Bergen i ti år fra 1973 og medlem i fylkestinget i Hordaland. I tillegg var han medlem i ulike styrer, slik som styreformann for Kysthospitalet i Hagevik og i Det medisinske selskap i Bergen. Der holdt han som 93-åring et engasjert foredrag om arrestasjonen av studenter i Oslo i 1942, der han selv bidro til å varsle flest mulig om planlagte arrestasjoner.

Eilertsen mottok mange utmerkelser og æresbevisninger, bl.a. krigsmedaljen, Ridder av St. Olavs Orden 1984, Order of The British Empire og æresmedlemskap i Det medisinske selskap.

Vi har satt stor pris på samarbeidet med Eilert Eilertsen. Våre tanker går til hans nærmeste nå som denne hedersmannen har avsluttet sin meget betydelige livsgjerning.

Publisert: 29. april 2014. Tidsskr Nor Legeforen. DOI: 10.4045/tidsskr.14.0339

(C) Tidsskrift for Den norske legeforening 2023. Lastet ned fra tidsskriftet.no 26. april 2023. 